УДК $551.435 .33(571.65)$

\title{
НОВЫЕ ДАННЫЕ О МОРФОЛОГИИ И ДИНАМИКЕ БЕРЕГОВОЙ ЗОНЫ БУХТЫ НАГАЕВА (Охотское море)
}

\author{
В. Н. Смирнов, Н. А. Горячев, О. Ю. Глуикова \\ ФГБУН Северо-Восточный комплексный научно-исследовательский институт \\ им. Н. А. Шило ДВО РАН, г. Магадан \\ E-mail:smirnovvn@yandex.ru
}

\begin{abstract}
Получены новые данные о динамике береговой линии бух. Нагаева за длительный период времени - с 1939 по 2016 г. Выделены 2 этапа, ограниченные датами аэрофотосъемки и орбитальной съемки: 1) 1939-1974 гг. и 2) 1974-2016 гг. Установлено, что за весь период, доступный для изучения (77 лет), береговая линия продвинулась в сторону суши на 56 м со средней скоростью 0.73 м/год. В течение первого этапа длительностью 35 лет под действием активной абразии береговая линия переместилась на 29 м со средней скоростью около 0.83 м/год. В течение второго этапа (42 года) смещение береговой линии существенно замедлилось, она продвинулась в сторону суши на 27 м со средней скоростью 0.64 м/год.
\end{abstract}

Ключевые слова: берег моря, бух. Нагаева, абразионный уступ, береговая линия, пляж, литораль.

DOI: $10.34078 / 1814-0998-2019-4-47-54$

\section{ВВЕДЕНИЕ}

Город Магадан расположен на возвышенной поверхности межгорной впадины, между акваториями бух. Гертнера и бух. Нагаева. Морским фасадом города является восточная часть бух. Нагаева, поскольку здесь находится морской торговый порт, через который Магадан связан морскими дорогами с Дальним Востоком. В последнее время состояние восточной береговой зоны бух. Нагаева привлекает большое внимание администрации и общественности Магадана. У горожан вызывает беспокойство то обстоятельство, что восточный береговой уступ бухты под действием волновой абразии и дождевой эрозии постоянно разрушается и неуклонно продвигается в сторону города, создавая реальную угрозу обрушения построенных на берегу объектов. Наиболее опасная ситуация сложилась в центральной части береговой зоны, где буквально в подвешенном состоянии находится рекреационная площадка с памятником первостроителям. Под такой же угрозой оказался и участок Портового шоссе, примыкающий к северной части берегового уступа, который подошел очень близко к дорожному полотну. Здесь положение усугубляется еще и тем обстоятельством, что уступ интенсивно разрушается 2019

(C) Смирнов В. Н., Горячев Н. А., Глушкова О. Ю., сверху вследствие эрозии, вызванной мощными дождевыми потоками со стороны дороги.

В ходе общественной дискуссии по этому поводу прозвучали различные предложения. Мы также представили свои соображения по этой проблеме в виде информационной записки в правительство Магаданской области. В нашей записке в общем виде обозначены основные характеристики развития береговой линии в настоящее время и предложены меры по предотвращению катастрофических последствий в условиях разрушающегося берегового уступа. Работа над этим документом в конечном счете выявила необходимость выполнения целенаправленных исследований по установлению динамики восточной береговой линии бух. Нагаева в течение длительного времени.

До последнего времени специальных работ по изучению динамики береговой линии восточного части бух. Нагаева за длительный период не проводилось. Выполнялись лишь не систематические, эпизодические визуальные наблюдения за образованием эрозионных и оползневых форм на поверхности берегового обрыва и его бровки (Важенин, 2017).

Наша работа выполнена с целью установить скорость смещения береговой зоны в сторону городских кварталов на восточном побережье бух. Нагаева за длительный период - с 1939 по 2016 г. и определить тенденции развития береговой зоны в будущем. 
Мы надеемся, что приведенные в статье результаты нашей работы позволят более обоснованно выработать принципиальный подход к решению обозначенной проблемы и решить главный вопрос: есть ли необходимость возводить разнообразные защитные сооружения (волноломы, буны, бетонированные волноотбойные стены и даже запроектированные в прибрежной акватории железобетонные аквакомплексы), как предлагают некоторые участники развернувшейся дискуссии, или принять какое-то альтернативное решение.

\section{ОБЩИЕ СВЕДЕНИЯ О ДИНАМИКЕ МОРСКИХ БЕРЕГОВ}

Изучение динамики морских берегов имеет большое значение как в теоретическом, так и в практическом отношении. Оно позволяет определить связи морфологии и морфометрии береговой зоны с новейшими и современными вертикальными движениями в области перехода от суши к морю, установить зависимость динамики береговой зоны от состава и структуры слагающих ее горных пород, от характера воздействия современных экзогенных процессов (обвальноосыпных, оползневых, эрозионных) и, в конечном счете, от интенсивности волновой абразии и тенденций в динамике береговой линии - трансгрессивных или регрессивных. В практическом отношении полученные результаты учитываются при гидротехническом строительстве в морских портах, при укреплении берегов и обосновании безопасного строительства в береговой зоне. Морская абразия отодвигает береговую линию в сторону суши и представляет неотвратимую угрозу для различных сооружений, расположенных на прибрежных территориях (жилых и промышленных зданий, дорог, мест отдыха и т. п.). Она активизирует развитие таких опасных для береговой инфраструктуры процессов, как дождевая эрозия, оползни и обвалы берегового уступа. Совместно с эрозионными процессами, которым абразия способствует, она сокращает пригодную для размещения промышленных и гражданских объектов прибрежную территорию.

Как известно, основную разрушительную работу в береговой зоне совершают штормовой прибой и, в меньшей мере, различные течения (прибрежные, донные), которые осуществляют транспортировку и аккумуляцию материала, поступающего с абразионного уступа. Скорость смещения береговой линии и ее морфология обусловлены различными факторами, в первую очередь, морфогенетическим типом морских берегов, литолого-петрографическим составом береговой зоны, прочностью горных пород абразионного уступа. Существенное значение имеют также гидрологические и метеорологические факторы: направление и сила ветра, приливы и отливы, береговые течения, длительность ледового покрова и его мощность. Приливы и отливы, а также морские береговые течения регулируют перенос и накопление обломочного материала вдоль береговой линии. Широкая литораль во время отливов эффективно препятствует проявлению абразионных процессов в береговом уступе и, таким образом, приводит к снижению скорости его продвижения в сторону суши. Кроме перечисленных, важным, но не однозначным фактором динамики берегового уступа является ледовое покрытие акватории в течение зимнего сезона, которое, с одной стороны, исключает волновое воздействие на береговой уступ, а с другой - льды производят разрушающее воздействие на берега, в особенности в начале зимы, в период становления ледового покрытия, и весной в период его деградации.

Положение береговой линии стабилизируется в фазу завершения формирования пляжа полного профиля, который защищает береговой уступ от абразии и, соответственно, от продвижения его в сторону суши. Вместе с тем верхняя часть уступа под действием эрозионных процессов еще некоторое время продолжит снижаться, а его бровка будет отступать в сторону суши вплоть до появления у берегового уступа угла естественного откоса и зарастания его поверхности травянистой и древесной растительностью, которые снижают эрозионное воздействие дождевых и талых вод.

\section{КРАТКАЯ ФИЗИКО-ГЕОГРАФИЧЕСКАЯ ХАРАКТЕРИСТИКА БЕРЕГОВ бУХ. НАГАЕВА}

Согласно морфогенетической классификации морских берегов (Сафьянов, 1978), северный и южный берега бух. Нагаева относятся к сбросово-бухтовому типу, а восточный - к абразионно-бухтовому типу (рис. 1). В соответствии с этим береговая линия имеет различное морфодинамическое выражение. Южный и северный берега представлены в основном линией контакта водной поверхности с крутыми обвально-оползневыми горными склонами, покрытыми крупноглыбовыми коллювиальными образованиями. Пляжи здесь отсутствуют. Восточная часть северного берега на протяжении 3.5 км образована линией контакта водной поверхности с узкой техногенной полосой, на которой размещена вся инфраструктура Магаданского торгового порта. Над нею возвышаются такие же крутые коллювиальные склоны, подрезанные территорией порта и полотном Портового шоссе. И северный, и южный берега бухты приурочены к неотектоническим разломам субширотного и северо-восточного простирания, которые в виде кулис прослеживаются вдоль 


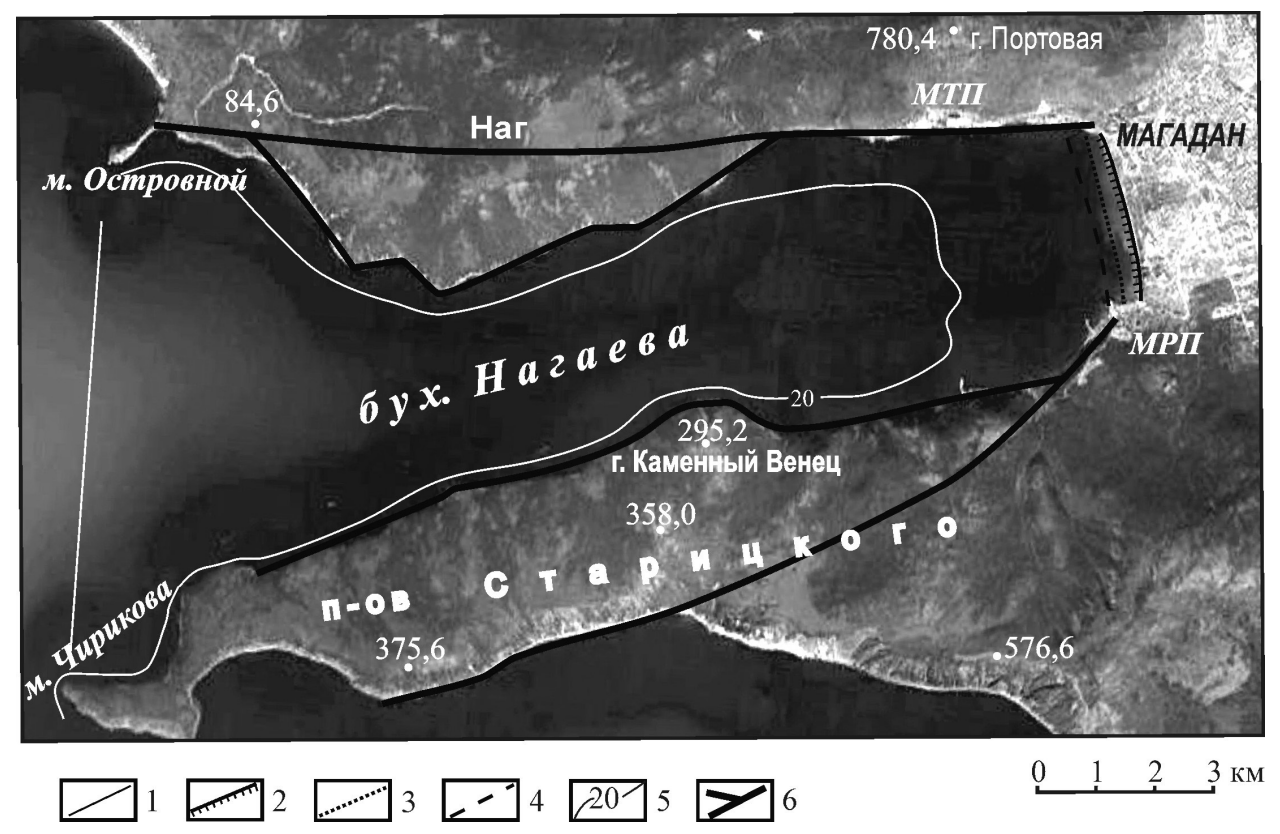

Puc. 1. Общий вид бух. Нагаева (снимок из интернет-ресурса Google Earth): 1 - морская граница бух. Нагаева; 2 - абразионный уступ; 3 - граница литорали; 4 граница прибрежного мелководья; 5 - изобата 20 м; 6 - неотектонические разломы. Буквенные обозначения: МТП - Магаданский торговый порт, МРП - Магаданский рыбный порт, Наг - Нагаевский разлом

Fig. 1. General view of the Nagayev Bay (Source: Google Earth): 1 - sea boundary of the Nagayev Bay; 2 - abrasion scarp; 3 - littoral boundary; 4 - coastal shoal boundary; 5 - $20 \mathrm{~m}$ isobath; 6 - neotectonic faults. МTП - Magadan Commercial Port, МРП Magadan Fishery Port, Наг - Nagayev Fault

морского побережья (Смирнов и др., 2000; Пахомов, Смирнов, 2002).

С востока бух. Нагаева ограничена абразионным уступом, выработанным в слабосцементированных песчано-галечных и песчано-глинистых отложениях нагаевской угленосной свиты миоценового возраста. Представленный рыхлыми, легко размываемыми породами неогена, восточный берег бух. Нагаева опирается флангами (южным и северным) на горные склоны, которые сложены прочными коренными породами (гранодиоритами Магаданского батолита), с большим трудом поддающимися абразии.

Границы восточной береговой зоны бух. Нагаева определяются по точкам резкого изменения простирания береговой линии с северо-северозападного на субширотное на севере (у Портового шоссе) и на восток-северо-восточное $\left(70^{\circ}\right)$ - на юге (у Марчеканского шоссе). Береговой уступ имеет длину около 2.5 км и дугообразную форму, выгнутую к востоку с максимальной величиной прогиба до 150 м в средней части. Прибрежная полоса представлена всхолмленным рельефом поверхности межгорной впадины, наибольшая высота которой 115 м н. у. м., зафиксирована примерно на равном расстоянии (1160-1200 м) от северного и южного фланга берегового уступа.
От этой точки, находящейся в 550 м к северозападу от береговой линии, поверхность Нагаевской межгорной впадины постепенно снижается на юг к Марчеканскому шоссе и на север - к Портовому. Высота абразионного берегового обрыва увеличивается в направлении с севера на юг: наименьшая (до 8-10 м) она в северной части у Портового шоссе, в центральной - 20 м, а в южной, у Марчеканского шоссе, местами достигает $40 \mathrm{M}$.

Южный участок берегового уступа на протяжении 1000 м наиболее сильно поражен эрозионными процессами, которые захватывают полосу побережья шириной до 150 м (рис. 2). На космическом снимке отчетливо видно, как поступивший со склонов в бухту эрозионный материал подхватывается береговым течением и переносится в северо-западном направлении, рассредоточиваясь в полосе шириной до 200 м.

К абразионному уступу прислонен пляж неполного профиля, в связи с чем береговая линия и в прошлом, и в настоящее время точно определяется уровнем стояния воды в приливы, от которого и отсчитывается высота абразионного уступа.

К пляжу примыкает полоса осушки. Ее ширина в фазе полного отлива 200-250 м. Поверхность литорали плавно смыкается с при- 


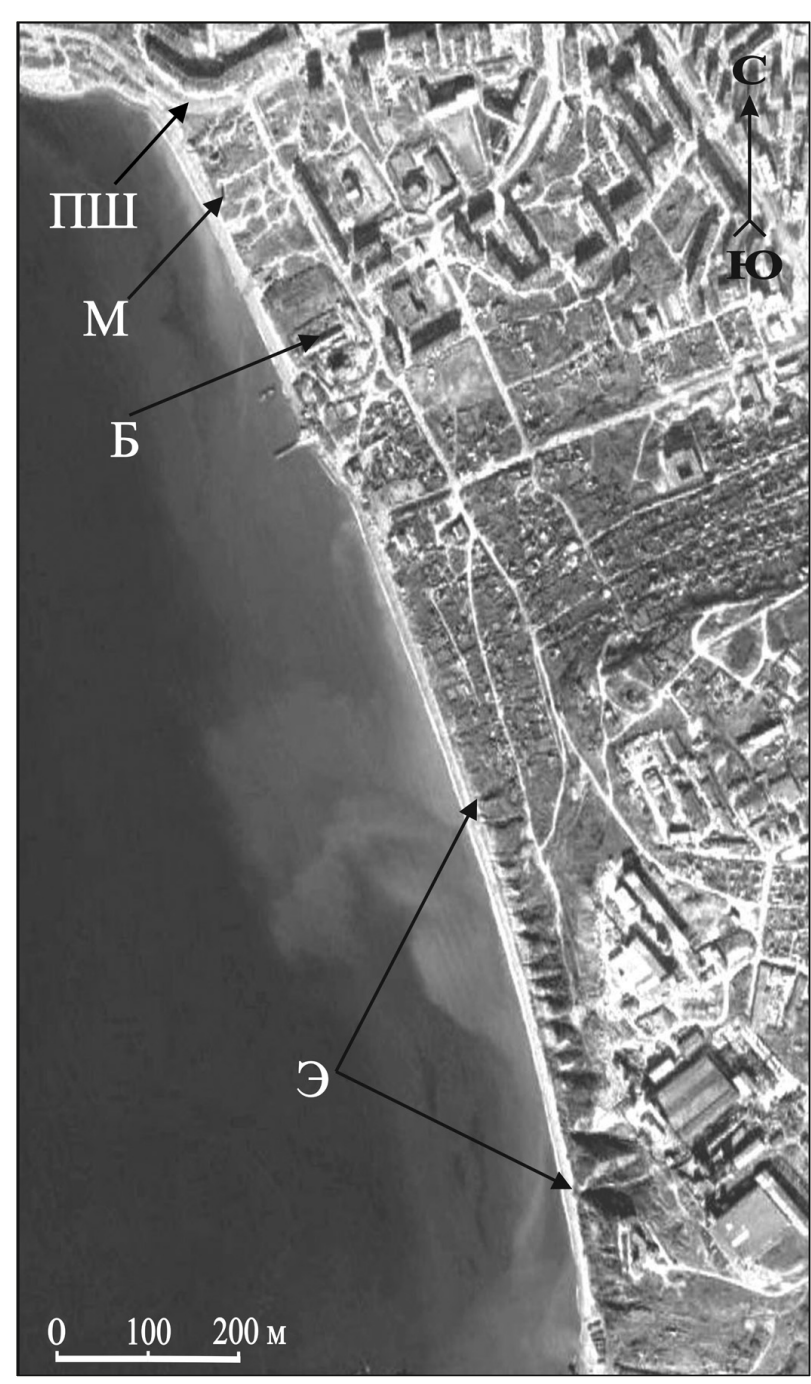

Puc. 2. Восточный берег бух. Нагаева (снимок из интернет-ресурса Google Earth). Буквенные обозначения: ПШ - портовое шоссе, М - маяк постройки 1960 г., Б - барак постройки до 1939 г., Э - интервал береговой зоны с развитием интенсивных эрозионных процессов

Fig. 2. East coast of the Nagayev Bay (Source: Google Earth). ПШ - Port Road; M - lighthouse built in 1960; Б - bunkhouse built before 1939; Э - coastal zone interval with intensive erosion processes developed

брежной отмелью (0.4-1.0 м), глубина дна на расстоянии около 0.5 км от берегового обрыва резко увеличивается до 7-12 м. Здесь происходит аккумуляция осадков, переносимых донными течениями.

Далее глубина постепенно увеличивается до 18-20 м. Извилистая изобата 20 м проходит на расстоянии около 2.5 км от берегового обрыва. На выходе из бухты, на траверзах м. Чирикова и Островной (около 15 км от берегового уступа) глубина около 34 м. Здесь дно бухты плавно смыкается с поверхностью Примагаданского шельфа, глубина которого на расстоянии 50 км к юго-западу от восточного берега бухты достигает $50 \mathrm{M}$.

Важными метеорологическими и гидрологическими особенностями бух. Нагаева, которые влияют на интенсивность абразии, являются высокие приливы с широкой полосой осушки и длительный период ледового покрытия акватории бухты (в течение 7 мес, с декабря по май).

\section{МЕТОДЫ И РЕЗУЛЬТАТЫ ИССЛЕДОВАНИЯ}

Выполненная работа в методическом отношении основана на сравнительном анализе аэрофотоснимков, сделанных в 1939 и 1974 г., а также космических снимков из интернет-ресурса ГУГЛ Планета Земля 2016 г. и крупномасштабных аэрофотоснимков с квадрокоптера DJI Phantom 3 Professional. На восточном побережье бух. Нагаева мы выявили несколько объектов, которые отражены на указанных дистанционных материалах и представляют собой надежные реперы для выполнения расчетов смещения береговой линии в сторону суши. Это бараки (пакгаузы) 1939 г., маяк 1960 г., а также некоторые элементы дорожной сети и городского строительства. Именно это обстоятельство, т. е. использование материалов разновременных аэрофотосъемок и современных средств дистанционного зондирования, позволило с высокой точностью определить расстояния, на которые смещалась береговая линия за указанный период, и вычислить скорости смещения за 3 интервала: 1939-1974 гг. - ранний интервал; 1974-2016 гг. - поздний интервал и 1939-2016 гг. - общее время смещения береговой линии. Кроме того, для ориентирования береговой зоны бух. Нагаева относительно городской инфраструктуры использован изданный план г. Магадана (Магадан, 1991).

\section{ДАННЫЕ АЭРОФОТОСЬЕМКИ 1939 г.}

В Магаданском краеведческом музее при содействии сотрудника музея А. С. Навасардова мы смогли воспользоваться несколькими крупномасштабными (1 : 8000) аэрофотоснимками залета 1939 г. (год приобретения Магаданом статуса города). На них достаточно отчетливо изображены восточное побережье бух. Нагаева, прибрежные ландшафты и инфраструктура строящихся городских районов Магадана. На рис. 3 представлено свидетельство того, что в береговой зоне отсутствуют пляжевые накопления, береговая граница выделяется по линии соприкосновения поверхности моря с абразионным береговым уступом. Кроме того, свидетельством активной морской абразии служит присутствие в береговой зоне крупного оползня прибрежной поверхности длиной около 300 м и шириной от 70 до 100 м. 


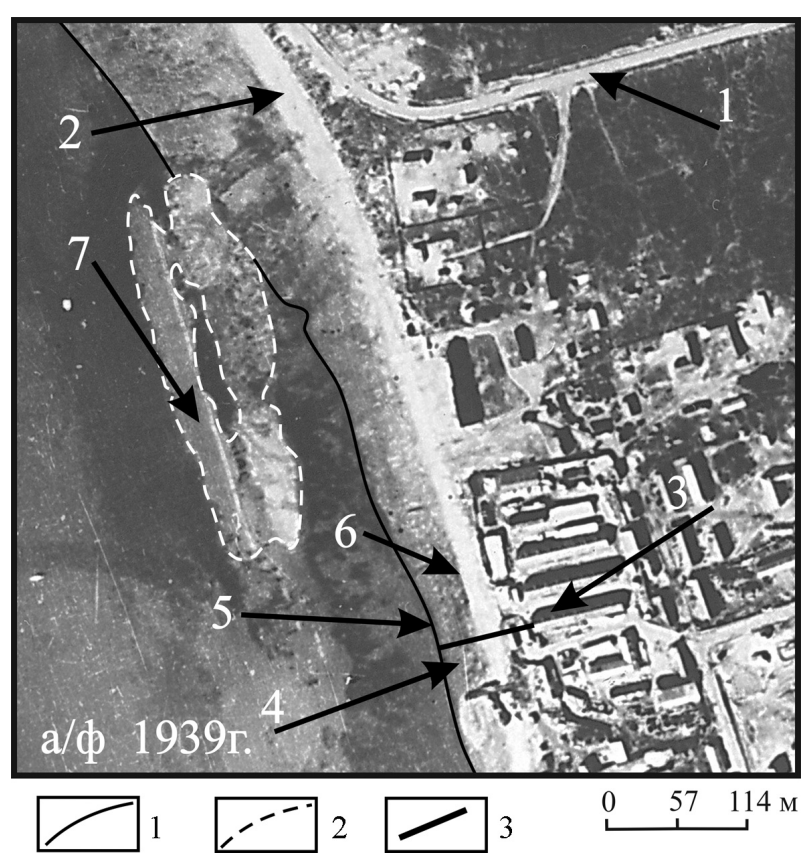

Puc. 3. Береговая зона бух. Нагаева в 1939 г. (аэрофотоснимок масштаба 1 : 8000): 1 - береговая линия; 2 - граница оползня; 3 - расстояние от барака до береговой линии. Стрелками обозначены: 1 - Портовое шоссе, 2 - проезд к складским постройкам, 3 - барак (пакгауз), 4-6- абразионный уступ (4-склон, 5 - подножье, 6 - бровка), 7 - тело оползня

Fig. 3. Nagayev Bay coastal zone in 1939 (airborne photo with scale $1: 8000$ ): 1 - coastline; 2 - landslide boundary; 3 - distance between the bunkhouse and the coastline. Arrows designate: 1 - Port Road; 2 - drive to warehouses; 3 - bunkhouse (warehouse); 4-6 - abrasion scarp (4 slope; 5 - foot; 6 - brow); 7 - landslide body

Наиболее важными для нашего исследования являются несколько техногенных объектов, которые существуют поныне. Это - часть Портового шоссе, бараки (пакгаузы), построенные и строящиеся на берегу бух. Нагаева, подъездная дорога к пакгаузам от Портового шоссе. Портовое шоссе имеет изменчивую ширину до 19.7 м. Ширина подъезда к береговым складским помещениям (пакгаузам), проложенного вдоль бровки берегового уступа, от 13 до 27 м.

На снимках установлено, что построенные и продолжающие строиться крупные сооружения барачного типа, которые представляли собой портовые закрытые складские помещения Нагаевского морского порта, находятся на расстоянии 82 м от подножья берегового уступа. Они были предназначены для кратковременного хранения поступающих морским путем разнообразных грузов перед отправкой их в Магадан и «на трассу», т. е. в поселки горнодобывающих предприятий. Эти строения отражены и на аэрофотоснимках 1974 г,, а крайний с юга барак сохранился до настоящего времени. Он ориен- тирован торцом к берегу бухты, имеет точно установленную длину (по коньку крыши), равную 80 м. Эти данные использованы нами в качестве масштабной линейки при определении размеров и пространственного расположения природных и техногенных объектов на аэрофотоснимках 1939 и 1974 г. Береговая линия, ее положение относительно пакгаузов в 2016 г. устанавливались в результате непосредственных наблюдений.

\section{ДАННЫЕ АЭРОФОТОСЬЕМКИ 01.09.1974 г. МАСШТАБА 1:21 500}

На снимках отражены большие изменения, произошедшие в Нагаевском районе Магадана с 1939 г. (рис. 4). Это касается и прибрежной территории: застроена ул. Приморская, возведены 2 створных маяка - на берегу бухты и за Приморской улицей в микрорайоне Моргородок. На берегу стоят четыре одинаковых барака (пакгауза), вокруг которых видна вереница большегрузных автомобилей, и другие сооружения. Расстояние от конька барака (пакгауза) до береговой линии 53 м. Расстояние от основания маяка до береговой линии 38 м.

\section{ДАННЫЕ ИЗ GOOGLE EARTH И АЭРОФОТОСЬЕМКИ С КВАДРОКОПТЕРА В 2016 г.}

На космоснимках и аэрофотоснимках, полученных с квадрокоптера (рис. 5), детально фиксируются ландшафтная обстановка и инфраструктура береговой зоны. Присутствие на берегу хорошо сохранившегося барака (пакгауза), конек которого имеет длину 80 м, позволяет, используя его как масштабную линейку, проводить достаточно точные измерения различных природных и техногенных объектов.

Основные параметры берегового обрыва:

высота абразионного уступа -8.7 м;

угол наклона современной поверхности уступа $-41^{\circ}$;

длина склона $-13.32 \mathrm{~m}$;

ширина основания уступа (отход от бровки) $11.4 \mathrm{M}$.

Обрыв задернован, подножье уступа в настоящее время стабильно.

Расстояние от конька барака (пакгауза) до береговой линии равно 26 м, до бровки абразионного уступа -15.6 м.

Все приведенные данные измерений расстояний между репером (коньком барака) и различными объектами в береговой зоне, а также между самими объектами опираются на отмеченную ранее «масштабную линейку», представленную коньком барака, длина которого 80 м. Погрешности измерений зависят от масштаба и разре- 


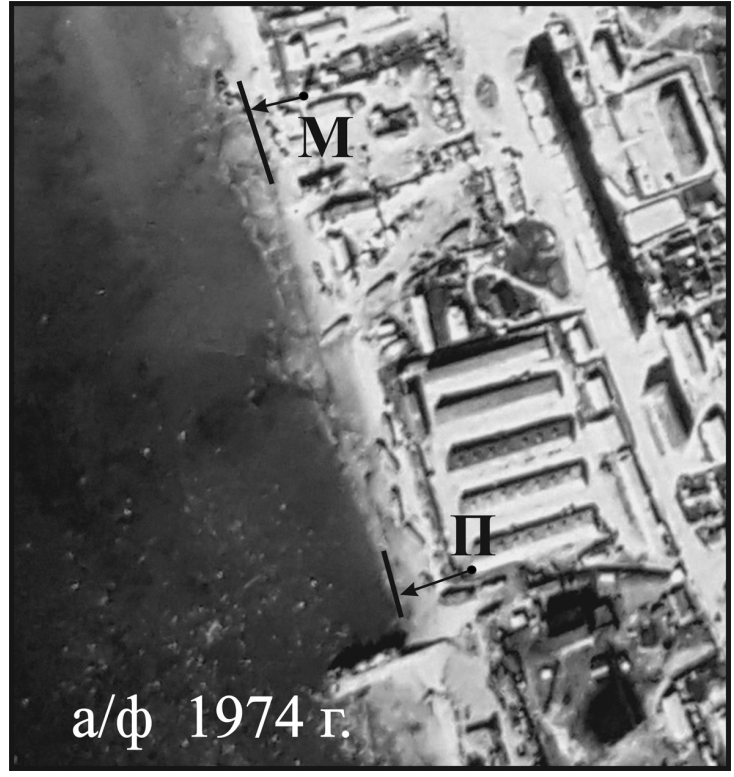

Puc. 4. Береговая зона бух. Нагаева в 1974 г. (аэрофотоснимок масштаба $1: 21$ 500). Условным знаком показаны расстояния от береговой линии до пакгауза и до маяка

Fig. 4. Nagayev Bay coastal zone in 1974 (airborne photo with scale $1: 21500$ ). The sign shows distances from the coastline to the warehouse and to the lighthouse

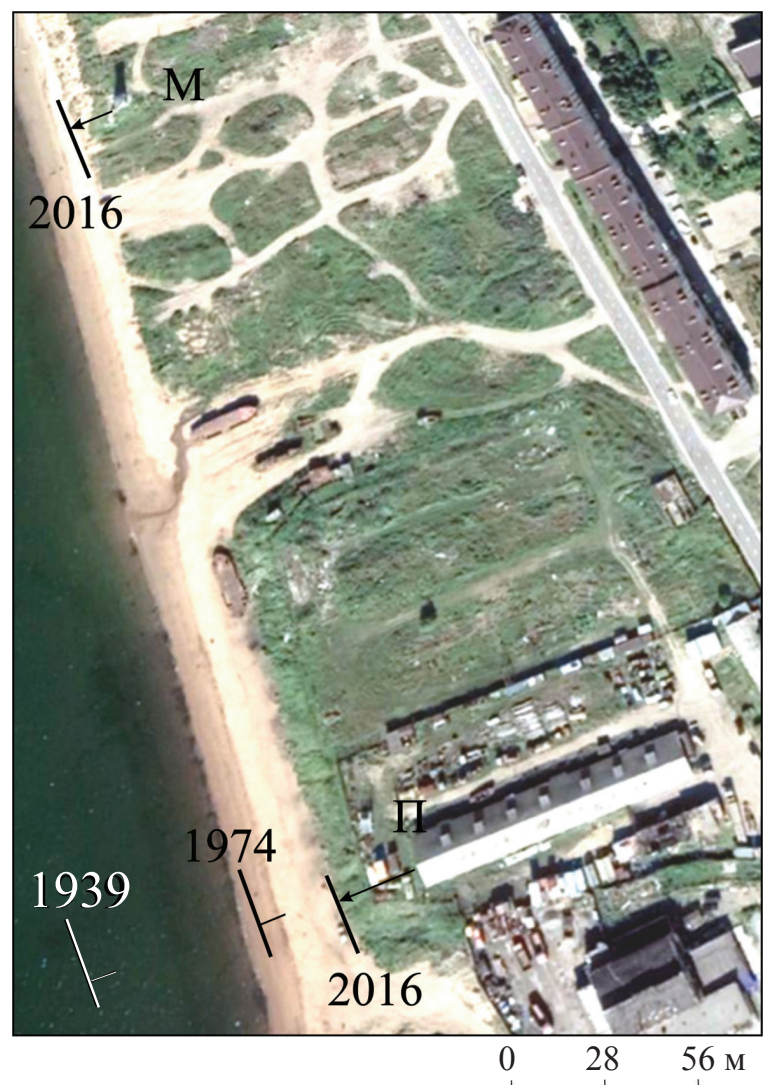

Puc. 5. Положение береговой линии в 1939-19742016 гг. (снимок из интернет-ресурса Google Earth)

Fig. 5. Coastline location in 1939-1974-2016 (Source: Google Earth) шающей способности отпечатков космических и аэрофотоснимков. Аэрофотоснимки 1939 г., хотя и относительно крупномасштабные (1:8000), имеют плохое качество отпечатков, поэтому точность измерений можно оценить как \pm 2 м. Снимки 1974 г. масштаба 1:21500 имеют отличное качество отпечатков, поэтому точность измерений на них, несмотря на меньший масштаб, также около \pm 2 м. Снимки 2016 г. с квадрокоптера и из Google Earth позволяют проводить измерения на них, которые могут поверяться измерениями непосредственно на местности. Погрешность измерения на них около 0.5 м.

На основе изложенных данных определены скорости продвижения береговой линии относительно береговых сооружений (пакгаузов) под действием абразии к востоку в следующие периоды: с 1939 по 1974 г., с 1974 по 2016 г. и за весь наблюденный период с 1939 по 2016 г. Дополнительно к этому получены данные о величине и скорости смещения береговой линии в период с 1974 по 2016 г. относительно маяка, построенного в 1960 г., который запечатлен на аэрофотоснимках 1974 г. (см. таблицу).

Весь восточный берег бух. Нагаева имеет естественную тенденцию к смещению в сторону города. Положение берегового обрыва стабилизируется, когда сформируется пляж полного профиля. Судя по тому, как протекают процессы на двух автоспусках к берегу бух. Нагаева, можно предположить, что для формирования пляжа полного профиля береговая линия должна сдвинутья в сторону города примерно на 20 м. При установленной скорости смещения 0.64 м в год, которая с течением времени будет уменьшаться, для этого потребуется около 35-40 лет.

Рассматривая сложившуюся ситуацию на восточном берегу бух. Нагаева, необходимо подчеркнуть, что здесь мы имеем дело с естественными процессами, которые никак не угрожают безопасности города и его населения до тех пор, пока человек не вступает в зону риска. Более того, за счет процессов разрушения уступа, сложенного песчано-галечным и песчано-глинистым материалом, формируется городской пляж - одно из любимых мест отдыха магаданцев. Поэтому вмешательство в ход естественного процесса в береговой зоне, нарушение динамического равновесия берега может привести к разрушению пляжа, активизации абразионных процессов и, соответственно, смещению береговой линии в сторону города. Следовательно, необходимо сохранить сложившуюся природную среду, только сделать ее более комфортной и привлекательной для отдыха. 
Данные о смещении восточного берега бух. Нагаева с 1939 по 2016 г.

Data on the shift of the Nagayev Bay east coast in 1939-2016

\begin{tabular}{|c|c|c|c|c|}
\hline $\begin{array}{l}\text { № } \\
\text { П/П }\end{array}$ & $\begin{array}{c}\text { Период времени, } \\
\text { интервал смещения }\end{array}$ & $\begin{array}{c}\text { Расстояние смещения } \\
\text { береговой линии, м }\end{array}$ & $\begin{array}{c}\text { Скорость } \\
\text { смещения, м/год }\end{array}$ & Примечание \\
\hline \multicolumn{5}{|c|}{ Положение и смещение береговой линии относительно барака (пакгауза) } \\
\hline 1 & $\begin{array}{c}\text { 1939-1974 гг. } \\
35 \text { лет } \\
82-53 \text { м } \\
\end{array}$ & 29 & 0.83 & $\begin{array}{c}\text { В начале периода - } \\
\text { крупные оползни } \\
\text { берегового уступа }\end{array}$ \\
\hline 2 & $\begin{array}{c}\text { 1974-2016 гг. } \\
42 \text { года } \\
53-26 \text { м }\end{array}$ & 27 & 0.64 & $\begin{array}{l}2016 \text { г. - данные } \\
\text { “Google Earth” } \\
\text { и аэросъемки } \\
\text { с квадрокоптера }\end{array}$ \\
\hline 3 & $\begin{array}{c}\text { 1939-2016 гг. } \\
77 \text { лет } \\
82-26 \mathrm{M} \\
\end{array}$ & 56 & 0.73 & \\
\hline \multicolumn{5}{|c|}{ Положение и смещение береговой линии относительно маяка } \\
\hline 4 & $\begin{array}{c}1974-2016 \text { гг. } \\
42 \text { года } \\
38-16 \text { м } \\
\end{array}$ & 22 & 0.52 & $\begin{array}{c}\text { Маяк поставлен } \\
\text { в } 1960 \text { г. }\end{array}$ \\
\hline
\end{tabular}

\section{ЗАКЛЮЧЕНИЕ}

На основании представленных в статье данных о динамике береговой линии в восточной части бух. Нагаева можно сделать следующие основные выводы:

в 1939 г. в береговой зоне полностью отсутствовал пляж, в связи с чем морская абразия была особенно интенсивной и сопровождалась крупными оползнями берегового уступа;

с 1939 по 2016 г. береговая линия бух. Нагаева неуклонно смещалась к востоку, в сторону Магадана и за 77 лет продвинулась на 56 м со средней скоростью $0.73 \mathrm{M} /$ год;

с 1939 по 1974 г. за 35 лет береговая линия переместилась к востоку на 29 м со средней скоростью 0.83 м/год.

С 1974 по 2016 г. наступление моря на сушу замедлилось, и береговая линия переместилась за 42 года на 27 м со средней скоростью 0.64 м/год.

В дальнейшем продвижение береговой линии будет происходить с нарастающим замедлением. Она стабилизируется, когда сформируется пляж полного профиля.

Не имеет смысла строить защитные береговые сооружения, которые нарушат сложившееся динамическое равновесие, приведут к уничтожению пляжа и, таким образом, спровоцируют последующее продвижение береговой линии в сторону города.

Вся зона между береговой линией и ул. Приморской шириной около 150 м должна быть превращена в рекреационную зону паркового типа без сооружения капитальных построек промышленного и гражданского назначения.

Приведенные в статье материалы могут послужить исходной позицией для регулярного мониторинга береговой линии как геодезическими методами, так и методом аэросъемки с квадрокоптера.

Авторы выражают благодарность старшему научному сотруднику Магаданского областного краеведческого музея А. С. Навасардову за предоставленную возможность познакомиться с аэрофотоснимками г. Магадана залета 1939 г., а также начальнику Маячной службы в Магадане В. Е. Лапшину за сведения о Магаданском маяке.

\section{ЛИТЕРАТУРА}

Важенин Б. П. Активизация обвально-оползневой деятельности в Магадане и его окрестностях в начале XXI в. // Чтения памяти акад. К. В. Симакова : Материалы докладов Всерос. науч. конф. (Магадан, 22-24 нояб. 2017 г.) / СВКНИИ ДВО РАН. Магадан : ИП Жарикова Т. В. , 2017. С. 23-26.

Пахомов А. Ю., Смирнов В. Н. Скальные оползни в горах Примагаданья // Геоморфология. 2002. № 3. C. $95-109$.

Сафьянов Г. А. Береговая зона океана в XX веке. М. : Мысль, 1978. 264 с.

Смирнов В. Н., Глушкова О. Ю., Пахомов А. Ю. Оползневые процессы в зоне Нагаевского активного разлома (район г. Магадана) // Геоморфология на рубеже XXI в. / IV Щукинские чтения. М. : МГУ, 2000. C. $88-92$.

Magadan. Plan Town. Scale of 1:15 000. Main Administration of Geodesy and Cartography under the Council of Ministers of the USSR. Moscow, 1991. 


\title{
NEW DATA ON THE MORPHOLOGY AND DYNAMICS OF THE NAGAYEV BAY COASTAL ZONE (Sea of Okhotsk)
}

\begin{abstract}
V. N. Smirnov, N. A. Goryachev, O. Yu. Glushkova
North-East Interdisciplinary Scientific Research Institute n. a. N. A. Shilo, FEB RAS, Magadan

The new data on the dynamics of the Nagayev Bay coastline over a long period of time (1939 through 2016) have been obtained. Confined by the dates of airborne photography and orbital survey, 2 stages have been distinguished: 1) 1939-1974 and 2) 1974-2016. It has been established that, over the whole 77 -year period available for studying, the coastline moved $56 \mathrm{~m}$ towards the dryland with the average speed $0.73 \mathrm{~m} / \mathrm{yr}$. During the first stage (35 yrs.), due to active abrasion, the coastline had moved $29 \mathrm{~m}$ towards the dryland with the average speed about $0.83 \mathrm{~m} / \mathrm{yr}$. During the second stage (42 yrs.), the coastline shift was significantly slower: $27 \mathrm{~m}(0.64 \mathrm{~m} / \mathrm{yr})$.
\end{abstract}

Keywords: coast, Nagayev Bay, abrasion scarp, coastline, beach, littoral.

\section{REFERENCES}

Magadan. Plan Town. Scale of 1 : 15 000, Main Administration of Geodesy and Cartography under the Council of Ministers of the USSR, Moscow, 1991.

Pakhomov, A. Yu.; Smirnov, V. N., 2002, Rockslides in Primagadanye Mountains, Geomorphologiya, 3, 95-109 [In Russian].

Safyanov, G. A., 1978, Coastal Zone of the Ocean in the $20^{\text {th }}$ Century, Moscow, Mysl' [In Russian].

Smirnov, V. N.; Glushkova, O. Yu.; Pakhomov, A. Yu., 2000, Landslide Processes in the Zone of the Nagayev
Active Fault (City of Magadan Area), Geomorphology on the Edge of the $21^{\text {st }}$ Century, IV Shchukin Readings, Moscow, Lomonosov Moscow State University, 88-92 [In Russian]. Vazhenin, B. P., 2017, Activation of Avalanching and Landsliding in Magadan and Its Vicinities in the Early $21^{\text {st }}$ Century, Readings in Memory of Academician K. V. Simakov, Materials of Reports of All-Russia Scientific Conference, Magadan, November 22-24, 2017, NEISRI FEB RAS, Magadan, SP Zharikova T. V., 23-26 [In Russian]. 